\title{
SPELEOTHEMS AND SPELEOGENESIS OF THE HYPOGENIC SANTA BARBARA CAVE SYSTEM (SOUTH-WEST SARDINIA, ITALY)
}

\author{
SIGE IN HIPOGENA SPELEOGENEZA JAMSKEGA SISTEMA \\ SANTA BARBARA (JZ SARDINIJA, ITALIJA)
}

\author{
Antonio PAGLIARA ${ }^{1}$, Jo DE WAELE ${ }^{1}$, Paolo FORTI ${ }^{1}$, Ermanno GALLI ${ }^{2}$ \& Antonio ROSSI ${ }^{2}$
}

\begin{abstract}
UDC 911:551.44(450)

Antonio Pagliara, Jo De Waele, Paolo Forti, Ermanno Galli \& Antonio Rossi: Speleothems and speleogenesis of the hypogenic Santa Barbara Cave System (South-West Sardinia, Italy)

This paper presents the results of a study on the speleogenesis and the speleothems and secondary mineralisations of the Santa Barbara Cave System in the Iglesiente Mining District (South-West Sardinia, Cagliari). This cave system, hosted in Cambrian carbonate rocks, has a very long geological history and its main voids have formed in hypogenic conditions. Nine speleogenetic phases can be recognised ranging in age between Cambrian and Holocene. Optical microscope and diffractometric analysis of active flowstone deposits have shown them being composed of alternating calcite and aragonite layers. The textural and chemical characteristics of these layers, obtained by SEM and EDAX analysis, suggest them to be related to variations in the depositional environment inside the cave, which in turn are probably correlated to external climatic oscillations.
\end{abstract} Keywords: cave morphology, speleothems, mineralogy, aragonite-calcite banding, speleogenesis.
Izvleček

UDK 911:551.44(450)

Antonio Pagliara, Jo De Waele, Paolo Forti, Ermanno Galli \& Antonio Rossi: Sige in hipogena speleogeneza jamskega sistema Santa Barbara (JZ Sardinija, Italija)

Članek predstavlja rezultate raziskav speleogeneze, sig in sekundarnih mineralov v jami Santa Barbara v rudnem območju Iglesiente na jugozahodni Sardiniji (Cagliari). Jama je razvita $\mathrm{v}$ kambrijskih karbonatih, pri čemer je večina glavnih rovov pa nastala $\mathrm{v}$ hipogenih pogojih. $\mathrm{V}$ obdobju med kambrijem in holocenom lahko razberemo devet speleogenetskih faz. Optične in uklonske analize sig kažejo na izmenjajoče se plasti kalcita in aragonita. Teksturne in kemične značilnosti sig smo raziskovali $\mathrm{z}$ vrstičnim elektronskim mikroskopom in elektronskim mikroanalizatorjem. Ugotovljene lastnosti so pogojene s sedimentacijskim okoljem $\mathrm{v}$ jami, ki pa je povezano s klimatskimi spremembami na površju.

Klučne besede: jamske skalne oblike, sige, mineralogija, kalcitno-aragonitni pasovi, speleogeneza.

\section{INTRODUCTION}

Santa Barbara show cave (SBC1) is a well known tourist attraction and is estimated to be one of the oldest caves in Italy (Forti \& Perna 1982). It is one of the most famous "mine caves" of Italy discovered in 1952 by excavations at level 195 m a.s.l. in the San Giovanni Mine (Iglesias, Sar- dinia) (Forti et al. 2005). After the closure of the mines this area became part of the 'Parco Geominerario della Sardegna' (Geomining Park of Sardinia), included in the UNESCO World Heritage List in 2001 (Arisci et al. 2002).

\footnotetext{
${ }^{1}$ Italian Institute of Speleology, University of Bologna, Via Zamboni 67 - 40126 Bologna, Italy, e-mail: jo.dewaele@unibo.it; paolo.forti@unibo.it

${ }^{2}$ Dipartimento di Scienze della Terra, University of Modena and Reggio Emilia, Largo S. Eufemia 19 - 41100 Modena, Italy, e-mail: antonio.rossi@unimore.it; gallier@unimore.it
}

Received/Prejeto: 29.04.2009 
The earliest studies in SBC1 were focused on the general morphological, mineralogical and environmental characteristics of the cave (Rossetti \& Zucchini 1956). The speleological exploration was carried out only 30 years later (Fabbri \& Forti 1986). The cave system is composed also of a lower branch, Santa Barbara Cave 2 (SBC2), discovered in 1985 (Fabbri \& Forti 1986). Although there is no physical connection between SBC1 and $\mathrm{SBC} 2$, speleological explorations and detailed surveys have demonstrated that they are part of the same system (SBCS), divided by a thin diaphragm of rock (Badino \& Messina 2005; Forti et al. 2005). SBC2, being developed $150 \mathrm{~m}$ below the show cave, shows extremely different morphologies and deposits (Bini et al. 1988), including a completely new corrosion form, the oxidation vent (De Waele \& Forti 2006).

A detailed inventory of dissolutional morphologies in both caves has been carried out in order to reconstruct the major phases of cave formation. Mineralogical, textural and geochemical analyses were performed on several samples drilled in the Quaternary carbonate speleothems of both SBC1 and SBC2 since $2005(\mathrm{~Pa}-$ gliara 2009). These morphological and mineralogical studies allowed to acquire further data on the speleogenetic evolution and on the depositional environment of this cave system.

\section{GEOLOGICAL SETTING}

The San Giovanni Mine is located in the Iglesiente Mining District (South-West Sardinia, Fig. 1). This area is characterised by Palaeozoic sediments deposited during two cycles: 1) Caledonian cycle from the Lower Cambrian to the Lower Ordovician, 2) Variscan cycle from Upper Ordovician to Upper Carboniferous, divided by the Sardinian unconformity (Bechstadt \& Boni 1996; Carmignani et al. 2001).

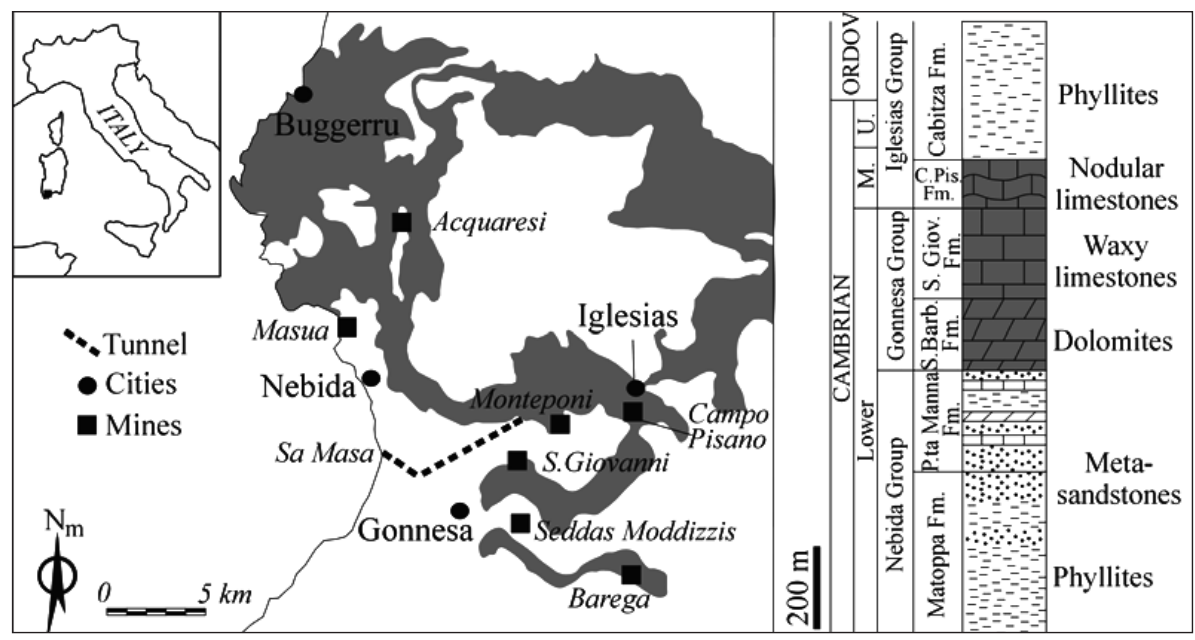

Fig. 1: Location map (left), geological setting (middle) and stratigraphic column for Iglesiente Mining District: carbonate outcrops are reported in grey and are also shown in the stratigraphic column. Santa Barbara Cave System is located in the San Giovanni Mine.

Mt. San Giovanni is located on the southern slope of the San Giorgio valley, and forms an elongated NE-SW trending ridge. It represents the southern limb of the Iglesias syncline (Civita et al. 1983), characterised by the Cambrian carbonate succession of Iglesias, once referred to as the "Iglesiente Metalliferous Ring", and now known as the Gonnesa Group (Bechstadt \& Boni 1996; Pillola 1989). The depositional sequence is composed, from bottom to top of: the Santa Barbara Formation consisting of "Dolomia Rigata", grey dolostones with clear sedimentary structures, the San Giovanni Formation, characterised by "Dolomia Grigia”, a whitish-grey intensely karstified limestone and of "Calcare Ceroide", a darker massive limestone. Finally on top of the carbonate sequence there are nodular limestones and phyllites of the Cabitza Formation (Middle CambrianLower Ordovician), which represent the core of the Iglesias syncline.

The actual structural settlement of the area was established by four deformative events: Sardinian Phase, before the Ordovician transgression, with a tectonic style with E-W direction; the first Variscan phase that follows previous deformations, emphasizing them; the Second Variscan phase with a straight stress with a N-S direction and the third Variscan phase with a variable axial direction and weak stresses. The Alpine Orogenesis only produced very weak deformations (Carmignani et al. 2001).

Mining activities exploited lead, zinc and silver polymetallic sulphide orebodies for more than 2,000 years in this area (Bechstadt \& Boni 1996). Polymetal- 
lic orebodies can be classified into pre-Variscan (stratabound or stratiform) and post-Variscan (skarns, vein and palaeokarst). The Mt. San Giovanni orebodies belong to the first type and are thus of Late CambrianLower Ordovician age (Boni \& Crescenzi 1988).

It is mainly thanks to these extensive industrial activities that many underground karst phenomena have been discovered. These 'mine caves' would otherwise not have been known, and their study has allowed reconstructing part of the speleogenetic history of this karst area. The most important of these is without a doubt the Santa Barbara Cave System (SBCS), subject of this paper.

\section{THE SANTA BARBARA CAVE SYSTEM (SBCS) AND ITS EVOLUTION}

The SBCS developed along the contact between the "Calcari Ceroidi" of San Giovanni and the "Dolomia Rigata" of Santa Barbara. The system is subdivided into two large cavities: SBC1 (from 180 to $227 \mathrm{~m}$ a.s.l.) and SBC2 (from 52 to $145 \mathrm{~m}$ a.s.l.) (Badino \& Messina 2005). The two environments develop along the same vertical plane and they are probably interconnected by means of discontinuities that cross the rock for a few tens of metres (Fig. 2). A detailed analyses of the mineralogy and morphology of the hosted speleothems proved without any doubt that the two caves were directly connected for a long period of time (Forti et al. 2005).

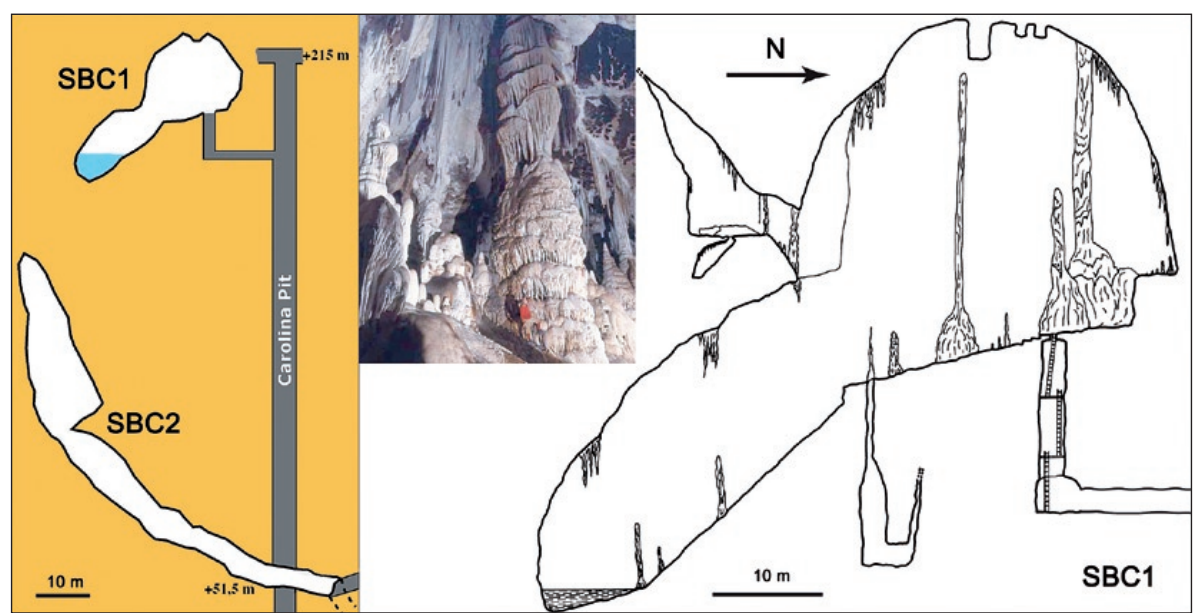

Fig. 2: Schematic profile of SBCS (left), of SBC1 (right). Inset shows the central part of the show cave.

Although the caves do not have a natural entrance and are accessible only through mine tunnels, their internal climate seems to be influenced by air exchanges happening at their small artificial entrances and by meteoric inputs. In $\mathrm{SBC} 1$, located not too far from the surface, cave climate is greatly influenced by the outside meteorological conditions. Cave air temperature in $\mathrm{SBC} 1$ ranges between 15.0 and $15.9^{\circ} \mathrm{C}$ with the coldest temperatures registered in August (Chiesi 2005).
Based on the regional geological evolution (Bechstadt \& Boni 1996) and a large set of observations carried out in many caves of Mt. San Giovanni (Forti et al. 2005) nine speleogenetic cycles have been recognised (Fig. 3). The first of these phases, leading to the widening of pre-existing fractures, occurred during a short emersion period of Cambrian age. A few small dissolution pockets observed close to the artificial entrance to SBC1 and filled with "Dolomia Gialla" (yellow dolomite), a secondary dolostone, are the only remnants of this stage. The second karst phase dates back to the Upper Cambrian/Lower Ordovician, when a large part of the carbonatic formations was exposed at the land surface thus inducing the development of some very evident karst phenomena. It is possible that this phase of intense karstification was controlled by the oxidation of polymetallic sulphide ores within the host rocks; the consequent presence of $\mathrm{H}_{2} \mathrm{SO}_{4}$ in the seeping waters gave rise to hyperkarst phenomena with the development of enhanced corrosional forms (Cigna 1978; De Waele et al. 2001). Marine conditions were re-established for a very long period (Middle Ordovician-Middle Carboniferous) and Mt. San Giovanni returned to continental conditions only during the $\mathrm{Va}$ riscan orogenesis towards the end of the Palaeozoic (Carmignani et al. 2001). Probably during this phase the SBCS acquired its actual size. In fact, at the base of the speleothems there are some alteration pockets filled with yellow dolomite, sulphides and sulphates (mainly barite) which, together with collapse breccias, were responsible for the infilling of most of the karst voids in the area. This 


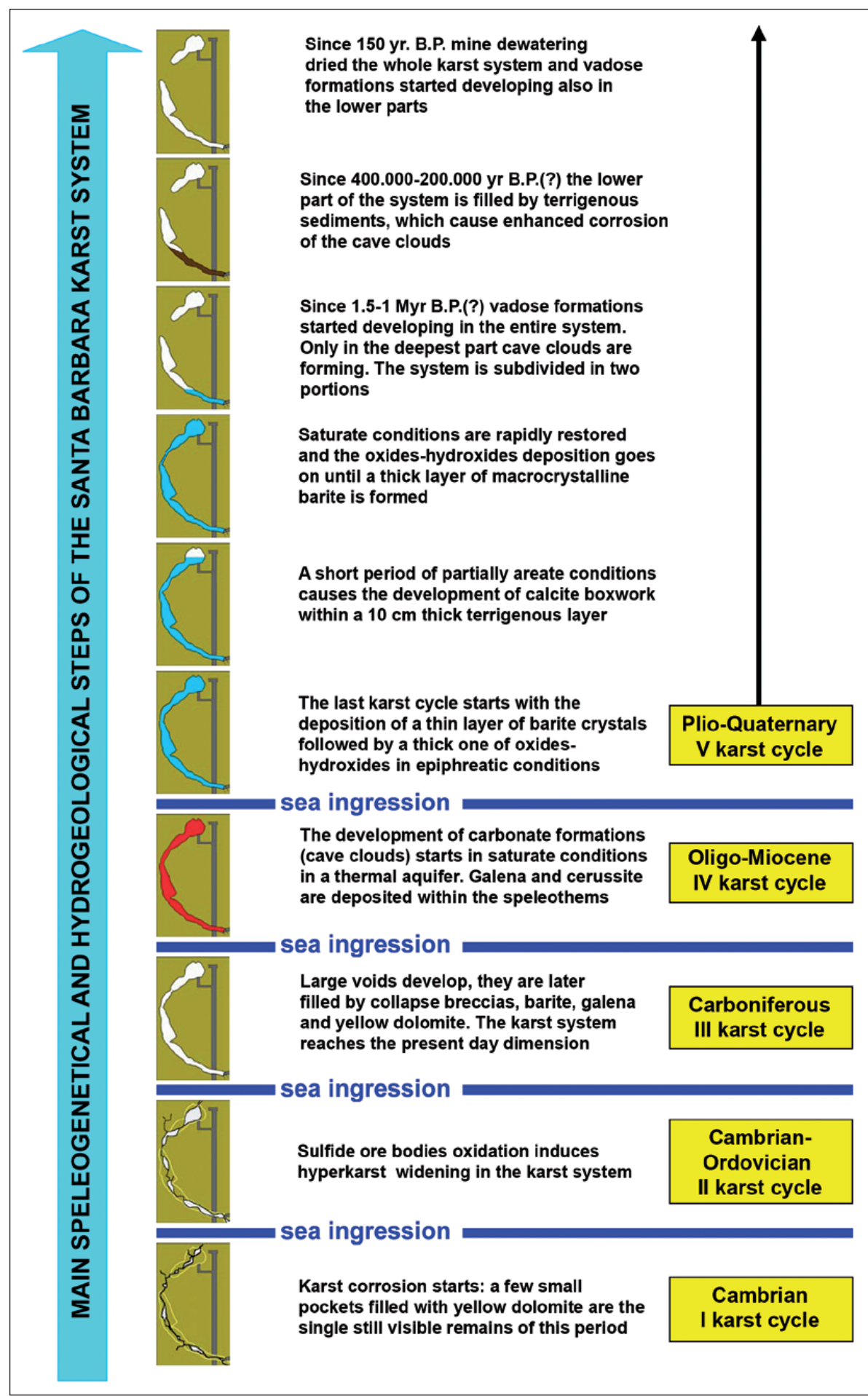

Fig. 3: Speleogenetic evolution of SBCS (From Forti et al. 2005). the opening of the Balearic and Tyrrhenian basins probably caused the circulation of warmer meteoric seeping water inside the system; this oxygen-rich water generated an intense alteration of sulphides and a partial remobilization of the ore bodies (Cortecci et al. 1989; De Vivo et al. 1987; Ludwig et al. 1989). During this stage, the walls of the entire karst system started to be covered with thick phreatic carbonate speleothems. Deposition in SBCS starts with centimetrewide dolomite crystals and red calcite crystals, the deposition of which occurred at temperatures over $40^{\circ} \mathrm{C}$ (Forti et al. 2005). Locally, close to the water table, cave clouds formed. Galena with some sphalerite and euhedral cerussite crystals has been observed within a core in one of these subacqueous speleothems (Forti et al. 2005).

The second phase of phreatic deposition occurred during Pliocene; in this period the temperatures of the seeping waters were lower than during the first phase. A thin layer of barite was the first to deposit, followed by large pockets of partially amorphous oxides- hydroxides together with clay minerals (mainly illite) as thin turbidity levels. The discovery of calcite mud cracks in a thin earthy layer testifies a short period in which SBC1, but not SBC2, experienced vadose conditions.

The phreatic conditions were soon restored, probably at the beginning of the Quaternary, and they lasted until the second - more important - event of barite deposition occurred. The growth of these large euhedral barite crystals occurred in the entire cave system and these 
crystals are still visible in SBC1, where they represent the principal aesthetic value of this cave. Similar crystals have also been observed in the upper parts of SBC2. Just after the end of the barite deposition the groundwater lowered, reaching the level of $130 \mathrm{~m}$ a.s.l. From this moment on SBC1 and the upper part of SBC2 started being filled with gravitational speleothems (stalagmites, stalactites, columns, flowstones, helictites etc.). Most of these speleothems are still active today. U/Th dating has shown that the cave clouds in the lower part of SBC2 stopped growing around 250,000 years ago (De Waele \& Forti 2006). At that time phreatic deposition stopped due to the arrival of large quantities of clay and earthy material that filled the bottom of SBC2 up to $55 \mathrm{~m}$ a.s.l. (Bini et al. 1988; De Waele \& Forti 2006). In these peculiar phreatic conditions the oxidation of the sulphides in the core of the cave clouds produced acid flows along cracks, which developed special corrosion morphologies named bubble trails and oxidations vents on the external surface of the cave clouds (De Waele \& Forti 2006). Finally the mining activities intersected $\mathrm{SBC} 2$ inducing the evacuation of most of the mud sediments, thus making this portion of the system accessible.

There are many morphologies that clearly demonstrate the hypogenic origin of most of the caves of Mt. San Giovanni. Also SBC1 and SBC2 are, in fact, composed of great chambers elongated along a fault, with bubble trails, cupola, megascallops, clearly showing the ascending flow of the dissolving waters (Klimchouk 2007, 2009).

\section{METHODS}

Speleothems in the SBCS have been sampled using a hand-held water-cooled HILTI electrical drilling machine in 2003 and 2005. The core of the drill was 5 or $8 \mathrm{~cm}$ in diameter and allowed to extract sample cylinders of up to $30 \mathrm{~cm}$ in length. For deeper drilling the operation was repeated using extensions, thus retrieving speleothem samples in separate but composable parts (Fig. 4). Recovery of the drill cores was better than $95 \%$.

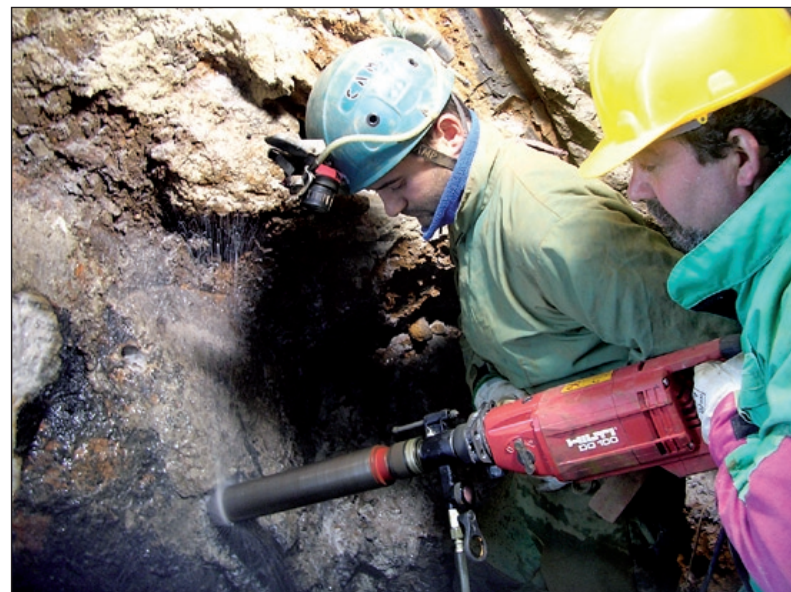

Fig. 4: Hand-held drilling in SBC1 (Photo: J. De Waele).

Three samples were drilled in SBC1 (SB1, SB2 and SB5 in Fig. 5), and two samples were taken in SBC2 (SB3 and SB4 in Fig. 5). For a detailed description of all drill cores the reader is referred to Pagliara (2009).

The samples have been embedded in resin epoxy plugs, then cut into four slices parallel to their axis with a water-cooled disk saw. The two central slices were used for the preparation of $47 \times 54 \mathrm{~mm}$ thin sections, the two external slices were polished and photographed with a scanner.

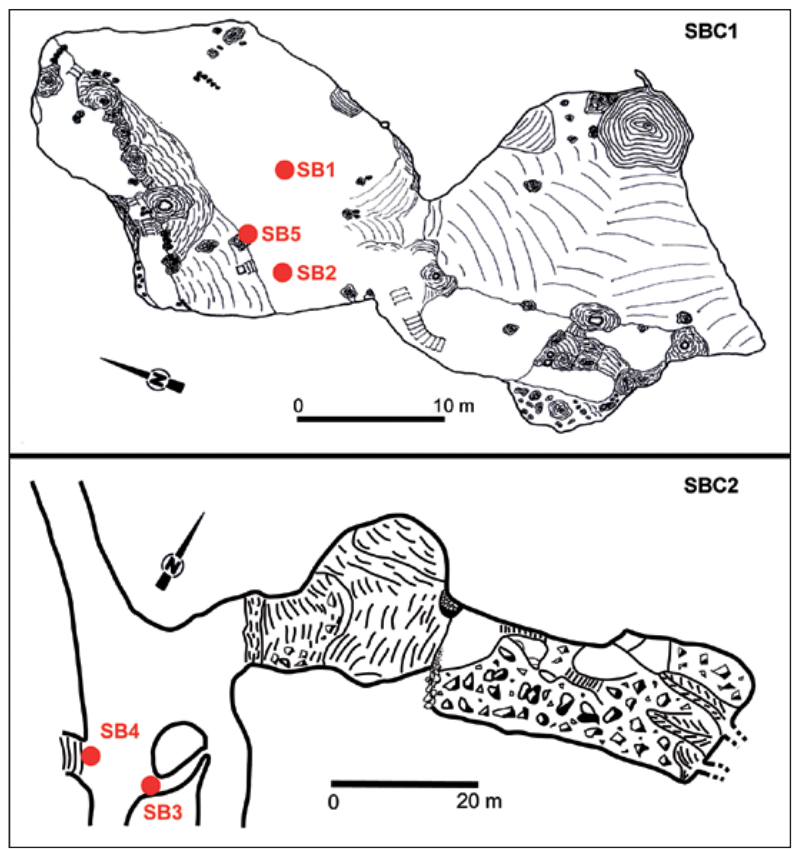

Fig. 5: Location of samples on the cave maps: SBC1 (top); $S B C 2$ (bottom).

A Leitz polarising microscope equipped with a Nikon Coolpix 995 was used for optical microscopy. Mineralogical analysis were carried out using a Philips PW 1050/25 powder diffractometer at $40 \mathrm{kV}$ and $20 \mathrm{~mA}$ (CuKa radiation, $\lambda=1.5418 \AA$, Ni filter). 
The quantitative chemical analysis has been carried out using a Philips XL40 Scanning Electron Microscope in combination with energy dispersive spectrometry (EDS-EDAX 9900).

An electron microprobe model ARL - SEMQ working at $15 \mathrm{kV}$ and $20 \mathrm{nA}$ with a beam of 6-10 $\mu \mathrm{m}$ diameter and equipped with an EDS has been used for point analysis of trace elements in the mineral samples.
$200 \mathrm{mg}$ of samples were used for U/Th dating at the Multicollector ICP-Mass Spectrometer facilities of the University of Bern. The high ${ }^{230} \mathrm{Th} / 2^{32} \mathrm{Th}$ ratios (comprised between 53 and 727) suggest the absence of residual Thorium. Ages were calculated using the half-lifes reported in Cheng et al. (2000).

\section{RESULTS AND DISCUSSION}

\section{DESCRIPTION OF SAMPLES}

All five drill cores are shown in Fig. 6.

SB1 was taken on the floor of SBC1 in the central part of the room. It is $36 \mathrm{~cm}$ long with a diameter of 8 $\mathrm{cm}$. Despite its shorter length, this core represents the entire depositional sequence in the SBCS, as shown by all drill cores, in a condensed manner. It is characterised by large amounts of barite and oxides/hydroxides.

SB2 was drilled in the floor immediately to the west of the tourist path at the base of a great white flowstone. It is $125 \mathrm{~cm}$ long and $8 \mathrm{~cm}$ in diameter and entirely composed of alternating calcite and aragonite layers.

SB5 was drilled a few meters north of SB2, closer to the entrance shaft, at the base of a high flowstone. It is $150 \mathrm{~cm}$ long and with a diameter of $5 \mathrm{~cm}$, and, as for SB2, does not reach the base of the Quaternary calcite-aragonite deposition. Most of the chemical and petrographical analyses have been carried out on this sample.

SB3, the first of the drill cores in SBC2, was taken at $3 \mathrm{~m}$ height in the artificial mine gallery where it cuts the lowest part of the natural cave. The core was drilled perpendicularly into a cave cloud of around $1.5 \mathrm{~m}$ diameter and is $87 \mathrm{~cm}$ long for a diameter of $8 \mathrm{~cm}$. It is composed of a thick layer of calcite, followed by a layer of barite crystals at $25 \mathrm{~cm}$ from the top, continuing downward with alternating layers of calcite and dolomite. This core reaches the centre of the cave cloud, characterised by the presence of galena, and goes on for another $10 \mathrm{~cm}$. A couple of U/Th datings ( 1 and 2 in Fig. 6) have been carried out at $9 \mathrm{~mm}$ and $216 \mathrm{~mm}$ from the top, giving ages of $246.9(+21 /-17) \mathrm{ka}$ and $399.6(+58 /-38) \mathrm{ka}$ respectively.

The other drill core (SB4) in SBC2 was taken in another cave cloud, but this time on the roof of the cave $10 \mathrm{~m}$ west of SB3. It is $125 \mathrm{~cm}$ long and $8 \mathrm{~cm}$ in diameter. On the contrary to SB3, no barite layer is encountered, the entire core being composed of calcite and dolomite. Also this sample encountered sulphides, this time composed of galena and sphalerite, at the centre of the cave cloud. Inside a vug in the galena several euhedral cerussite crystals were found.

Besides calcite, aragonite, dolomite, barite, galena, sphalerite and cerussite other 11 minerals have been identified in the SBCS drill cores, including many oxides and hydroxides (Tab. 1) (Forti et al. 2005).

\section{MINERALOGICAL, PETROGRAPHICAL AND CHEMICAL ANALYSES}

Sample SB5 is composed of an alternation of aragonite and calcite layers, and of layers where the aragonite crystals were transformed into calcite crystals. Aragonite is predominant and of larger thickness. At the electronic microscope the calcite crystals appear elongated, with length-width ratio $\leq 6$, organized in a columnar fabric. These crystals show few structural deformations and grow in perfect optical continuity with the lower ones, despite the presence of clay 


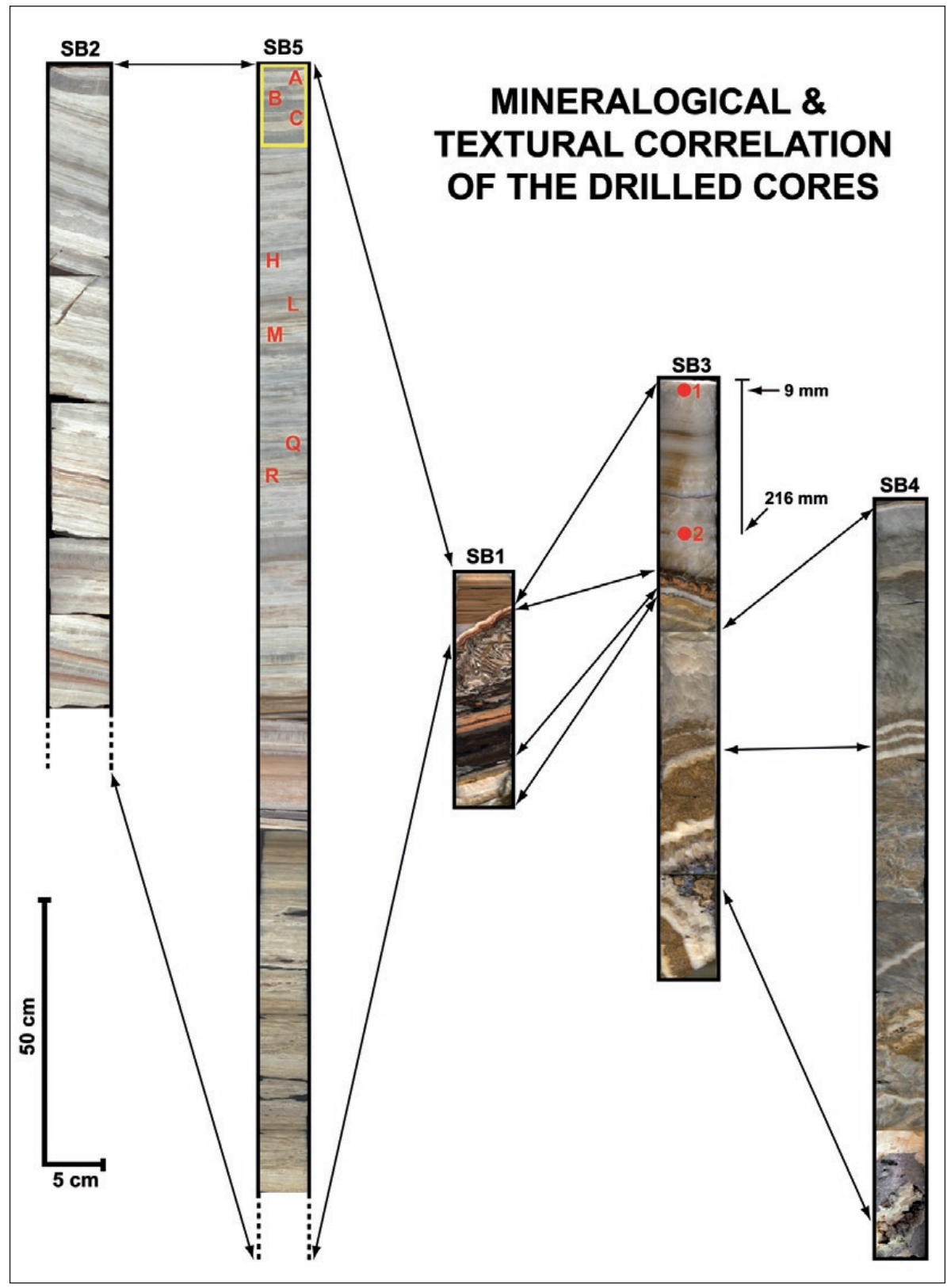

Fig. 6: Samples, from left to right: SB2, SB5 and SB1 taken in SBC1, and $S B 3$ and SB4 in SBC2. The yellow quadrangle in SB5 indicates the apical part shown in Fig. 14. Letters in SB5 indicate electron microprobe analysis (see Tab. 2). Two numbered dots in SB3 are U/Th datings carried out on this cave cloud.

impurities which did not stop the growth of each individual crystal. In some cases growth-blades have been observed, both by optic and by electronic microscope (Fig. 7). Thin bands are visible using UV light because of the presence of humic and fulvic acids in the crystalline lattice (Fig. 8) (Pagliara et al. 2008).

Also the aragonite individuals are elongated (with a length-width ratio greater than 6) with sharp apical terminations, and originally organized in a fan texture, becoming needle-shaped in the next growth phase (Fairchild et al. 2000) (Fig. 9).

The two phases of calcium carbonate, as said above, are often overlapped one upon the other, in layers which show a gradual change from the first to the second phase. Detailed analysis

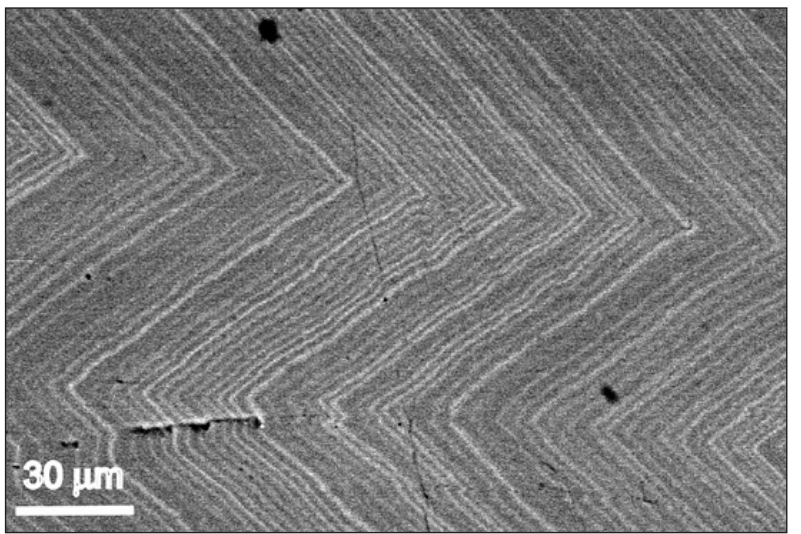
has shown many different phases of the transformation of aragonite into calcite and never the opposite. Consequently, two main different morphologies, resulting form the different graduation of the diagenetic process, have been observed. The two extreme polymorphic cases are: a) the aragonite with needle-shaped texture, b) the calcite crystals aggregated as mosaic, "equant calcite" (Railsback 2000).

Fig. 7: Pure calcite crystals with a palisade texture and clear growth banding with a sawtooth boundary (SEM photograph). The bands show the succession of growth phases of the apical parts of the crystals. 


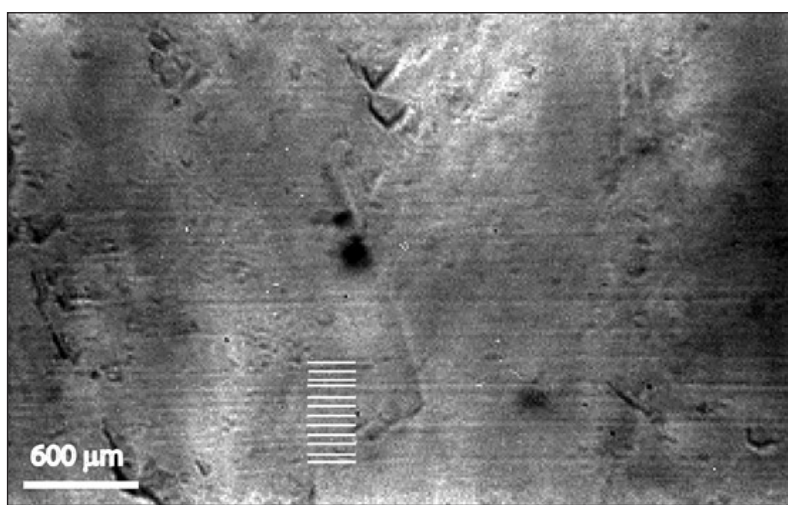

Fig. 8: Luminescent growth bands (zoom 640x). The banding is visible in short wave UV light.

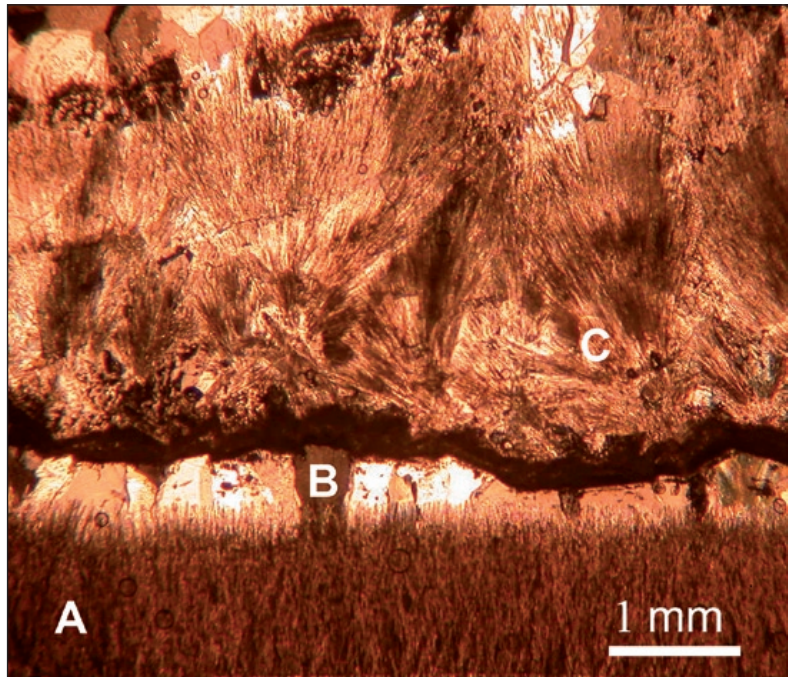

Fig. 9: Thin section of the final part of the Santa Barbara sample SB5 (optical microscope): from bottom to top it is possible to see: A) deposition of an aragonite level; B) a level of mosaic calcite crystals, produced by the transformation of aragonite into calcite; C) a level that shows the first phase of transformation of aragonite into calcite: the aragonite fans, at which vertexes an impurity level starts, grow on small polygonal calcite crystals with rounded borders, leaving several empty spaces between the crystals.

If the transformation develops only in a partial way the resulting morphology shows acicular (needle-like) aragonite crystals with a fan texture overlapping on the calcite polygonal crystals. These last ones do not have an euhedral shape but in fact show rounded borders with several empty spaces between the individual crystals (Figs. 10 \& 11).

The morphology resulting from a more advanced phase of transformation is constituted by calcite crystals having definite borders, organized in a mosaic texture, inside which it is possible to see, only at strong magnification, the aragonite crystals defined "relics" (Frisia 1996). These are concentrated in the central part of the

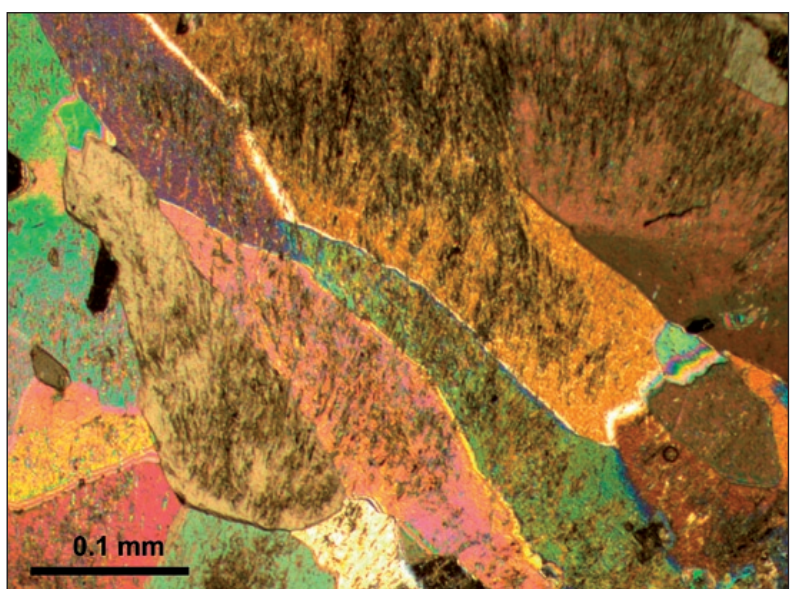

Fig. 10: $I^{\text {st }}$ phase of transformation of aragonite into calcite (optical microscope). The polygonal calcite crystals are rounded and show many empty spaces in between crystals (white areas around crystals).

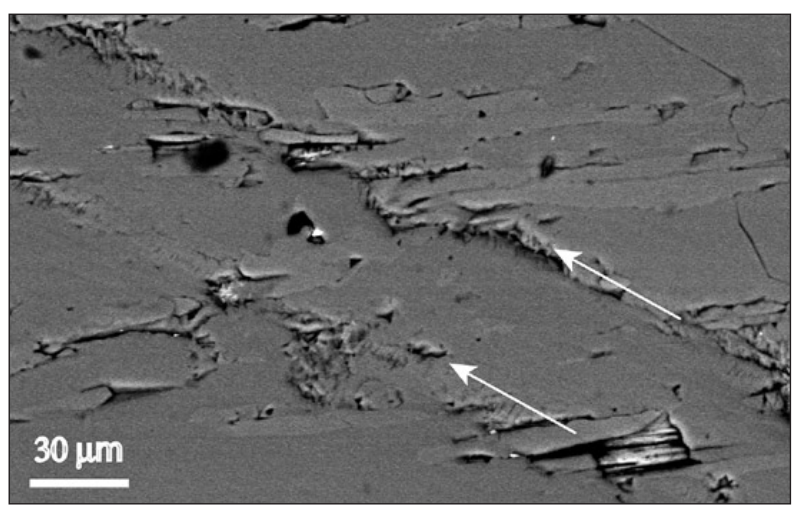

Fig. 11: SEM photograph of the first A-C transformation phase; the hazy boundaries of the rounded calcite crystals and the bands of the apical terminations of the aragonite crystals are clearly visible (arrows).

calcite polygons, the empty spaces, created during the first phase of the transformation, are completely occupied by the calcite individuals. The "relic" crystals of aragonite are well visible in the pictures obtained by optical and electronic microscope respectively (Figs. 12 \& 13). When the transformation is very advanced but not complete, the transition from aragonite into calcite is visible also at naked eye (Fig. 14).

In summarising the flowstone deposit of SB5, four different textures have been recognised: 1) columnar calcite; 2) needle-shaped and/or fan-shaped aragonite; 3) mosaic crystals of calcite crossed by aragonite crystals, as a result of the low grade $\mathrm{A} \rightarrow \mathrm{C}$ transformation and, $\mathrm{fi}$ nally 4) mosaic calcite including "relics" of aragonite, as a result of the high grade $\mathrm{A} \rightarrow \mathrm{C}$ transformation.

The precipitation of the two polymorphics might be linked to variations of the $\mathrm{Mg}$ content in the concretion- 


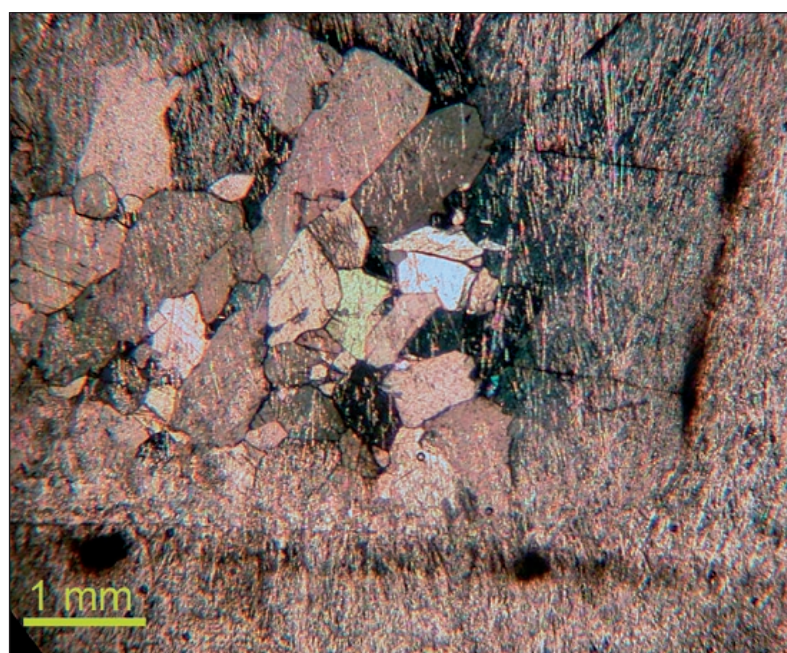

Fig. 12: II ${ }^{\text {nd }}$ phase of A-C transformation (optical microscope); calcite crystals with neater boundaries lack the intercrystalline voids.

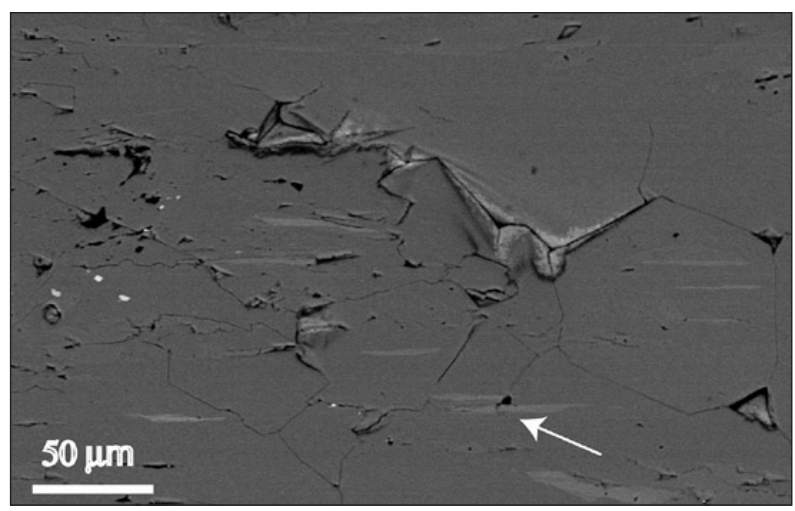

Fig. 13: SEM photograph of polygonal calcite crystals and some rare "relic" acicular aragonite crystals (arrows).

ary water (Frisia et al. 2002). This hypothesis is strengthened by the fact that the karst system develops at the contact between limestones and dolostones, and high concentrations of magnesium are present in the calcite layers and in the cave water (Frau et al. 2005).

However, results from chemical analysis (Fig. 15 and Tab. 2) and examination of the geometric relations between the different fabrics of crystals by optic and electronic microscopes, have shown the great importance that other ions have on these deposits and transformations. $\mathrm{Pb}^{2+}, \mathrm{Ba}^{2+}$ and $\mathrm{Sr}^{2+}$ inhibit the growth of calcite crystals and promote the deposition of aragonite. $\mathrm{Fe}^{2+}$ promotes calcite deposition and $\mathrm{Mg}^{2+}$, at small concentrations, promotes the deposition of $\mathrm{Mg}$-rich calcite, while at higher concentrations (molar ratio $\mathrm{Mg} / \mathrm{Ca}$ equal to 2.5) promotes the deposition of aragonite; in this case, since $\mathrm{Mg}^{2+}$ cannot enter the crystal lattice of aragonite, it remains in solution in the cave water.

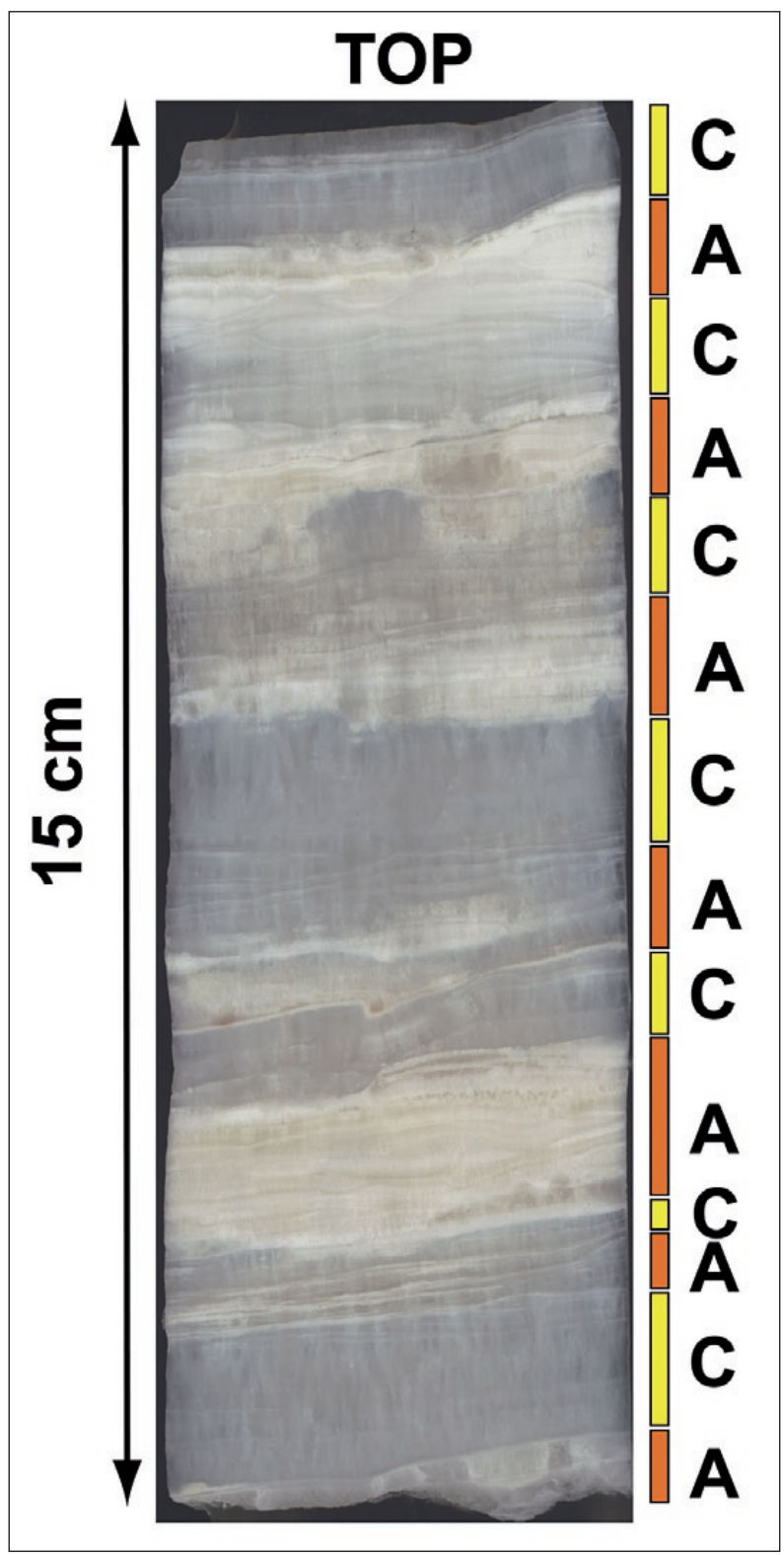

Fig. 14: Thin section of the apical part of the flowstone speleothem SB5 with indication of Aragonite $(A)$ and Calcite $(C)$ layers (for location see Fig. 6): The growth layers and the levels in which transformation already took place are clearly visible.

The presence of the above ions is due to a washing away and the remobilization of the local sulphide ore deposits during the Oligo-Miocene by thermal waters (De Waele \& Forti 2006; Forti et al. 2005). Sulphates, such as barite, and another mix of ions were also redeposited inside the speleothems because of the circulation of oxygen-rich percolating meteoric waters generating oxidation processes of the above sulphides, causing their further mobilisation.

The possibility of mobilisation from the rock of $\mathrm{Pb}^{2+}, \mathrm{Ba}^{2+}, \mathrm{Sr}^{2+}, \mathrm{Zn}^{2+}, \mathrm{Fe}^{2+}$ and $\mathrm{Mg}^{2+}$ depends both on 
Table 2 - Chemical composition obtained by electron microprobe on aragonite and calcite layers in the apical part of speleothem SB5 shown in Fig. 14 (see Fig. 6 for location and Fig. 15 for graphs).

\begin{tabular}{|c|c|c|c|c|c|c|}
\hline Sample & Mineral & $\mathrm{MgO}$ & $\mathrm{BaO}$ & $\mathrm{SrO}$ & $\mathrm{PbO}$ & $\mathrm{Fe}_{2} \mathrm{O}_{3}$ \\
\hline A1 & $C$ & 1.292 & 0.001 & 0.157 & 0.009 & 0.157 \\
\hline$A 2$ & $C$ & 1.086 & 0.001 & 0.001 & 0.043 & 0.047 \\
\hline A3 & $A$ & 0.012 & 0.091 & 0.025 & 0.076 & 0.001 \\
\hline A4 & $C$ & 1.083 & 0.061 & 0.001 & 0.195 & 0.195 \\
\hline B1 & $A$ & 0.001 & 0.035 & 0.099 & 1.375 & 0.001 \\
\hline B2 & A & 0.001 & 0.017 & 0.001 & 0.462 & 0.001 \\
\hline B3 & A & 0.001 & 0.023 & 0.297 & 0.101 & 0.001 \\
\hline B4 & A & 0.001 & 0.001 & 0.147 & 0.074 & 0.001 \\
\hline B5 & A & 0.001 & 0.001 & 0.001 & 0.66 & 0.001 \\
\hline B6 & $A$ & 0.001 & 0.005 & 0.001 & 0.001 & 0.001 \\
\hline B7 & $A$ & 0.125 & 0.001 & 0.276 & 2.36 & 0.001 \\
\hline B8 & $A$ & 0.001 & 0.027 & 0.045 & 0.88 & 0.001 \\
\hline B9 & $A$ & 0.001 & 0.011 & 0.094 & 0.001 & 0.001 \\
\hline B10 & A & 0.001 & 0.214 & 0.381 & 0.576 & 0.001 \\
\hline B11 & A & 0.001 & 0.001 & 0.134 & 0.941 & 0.001 \\
\hline B12 & A & 0.009 & 0.021 & 0.229 & 0.399 & 0.001 \\
\hline B13 & A & 0.001 & 0.011 & 0.25 & 0.055 & 0.001 \\
\hline B14 & $A$ & 0.001 & 0.001 & 0.394 & 0.469 & 0.001 \\
\hline $\mathrm{C} 1$ & $A$ & 0.001 & 0.08 & 0.079 & 0.041 & 0.001 \\
\hline $\mathrm{C} 2$ & $C$ & 1.094 & 0.012 & 0.0001 & 0.28 & 0.28 \\
\hline C3 & $C$ & 1.037 & 0.042 & 0.0001 & 0.001 & 0.042 \\
\hline $\mathrm{C} 4$ & $C$ & 0.933 & 0.005 & 0.049 & 0.076 & 0.076 \\
\hline $\mathrm{C} 5$ & C & 1.015 & 0.055 & 0.055 & 0.052 & 0.052 \\
\hline C6 & $C$ & 0.954 & 0.001 & 0.025 & 0.001 & 0.025 \\
\hline C7 & $A$ & 0.001 & 0.001 & 0.229 & 0.029 & 0.001 \\
\hline $\mathrm{C} 8$ & A & 0.008 & 0.001 & 0.077 & 0.001 & 0.035 \\
\hline C9 & C & 0.822 & 0.001 & 0.001 & 0.035 & 0.155 \\
\hline C10 & C & 0.981 & 0.006 & 0.001 & 0.155 & 0.064 \\
\hline C11 & $C$ & 0.928 & 0.017 & 0.224 & 0.064 & 0.001 \\
\hline $\mathrm{H} 1$ & A & 0.001 & 0.029 & 0.001 & 0.001 & 0.001 \\
\hline $\mathrm{H} 2$ & A & 0.003 & 0.061 & 0.078 & 0.001 & 0.001 \\
\hline $\mathrm{H} 3$ & A & 0.001 & 0.006 & 0.238 & 0.001 & 0.001 \\
\hline $\mathrm{H} 4$ & A & 0.001 & 0.005 & 0.209 & 0.043 & 0.001 \\
\hline H5 & $A$ & 0.001 & 0.043 & 0.263 & 0.144 & 0.001 \\
\hline L1 & A & 0.014 & 0.001 & 0.001 & 0.007 & 0.001 \\
\hline L2 & A & 0.001 & 0.036 & 0.359 & 0.023 & 0.001 \\
\hline L3 & $A$ & 0.004 & 0.001 & 0.001 & 0.001 & 0.001 \\
\hline M1 & A & 0.055 & 0.001 & 0.128 & 0.001 & 0.001 \\
\hline M2 & $A$ & 0.002 & 0.003 & 0.172 & 0.106 & 0.001 \\
\hline M3 & A & 0.043 & 0.059 & 0.28 & 0.032 & 0.001 \\
\hline M4 & A & 0.024 & 0.001 & 0.076 & 0.001 & 0.001 \\
\hline M5 & A & 0.033 & 0.001 & 0.051 & 0.033 & 0.001 \\
\hline M6 & C & 1.22 & 0.012 & 0.001 & 0.001 & 0.012 \\
\hline M7 & $C$ & 1.044 & 0.001 & 0.001 & 0.182 & 0.182 \\
\hline M8 & A & 0.001 & 0.001 & 0.001 & 0.001 & 0.001 \\
\hline $\mathrm{R} 1$ & $A$ & 0.001 & 0.001 & 0.001 & 0.041 & 0.001 \\
\hline $\mathrm{R} 2$ & $C$ & 0.034 & 0.074 & 0.001 & 0.009 & 0.001 \\
\hline R3 & A & 0.001 & 0.017 & 0.001 & 0.089 & 0.001 \\
\hline R4 & $A$ & 0.001 & 0.087 & 0.172 & 0.001 & 0.001 \\
\hline
\end{tabular}

the duration of presence of the percolating waters in the rock and on the temperature of these waters. A high value of infiltration indicates plenty of rain that increases the percolation of water, reducing the time of water-rock interaction, thus making the dissolution of ions other than $\mathrm{Ca}^{2+}$ and $\mathrm{Mg}^{2+}$ less likely; in this way hydrochemical conditions probably favoured the deposition of calcite and/or magnesium-rich calcites. On the contrary, periods with little rain and with higher temperatures allow for longer water-rock interactions, creating thus solutions rich in the less soluble ions. In these conditions, the concentration of $\mathrm{Pb}^{2+}, \mathrm{Ba}^{2+}, \mathrm{Sr}^{2+}$ and $\mathrm{Mg}^{2+}$ are much higher in comparison to those of $\mathrm{Zn}^{2+}$ and $\mathrm{Fe}^{2+}$, favouring the deposition of aragonite. Finally the oxidation processes often mark the beginning of aragonite precipitation with the deposition of thin layers of oxides and hydrated hydro-oxides of the metals that promote its formation (Forti et al. 2005).

In general aragonite layers are far more abundant than calcite layers in the SBC1 speleothems, mainly as the result of the polymorphic transformation. In the last $15 \mathrm{~cm}$ from the top of the speleothem calcite crystals are present both with the typical texture of a primary precipitation with columnar and mosaic fabric and with the texture resulting by the transformation process. In particular the repetition seems to reflect three different depositional events: 


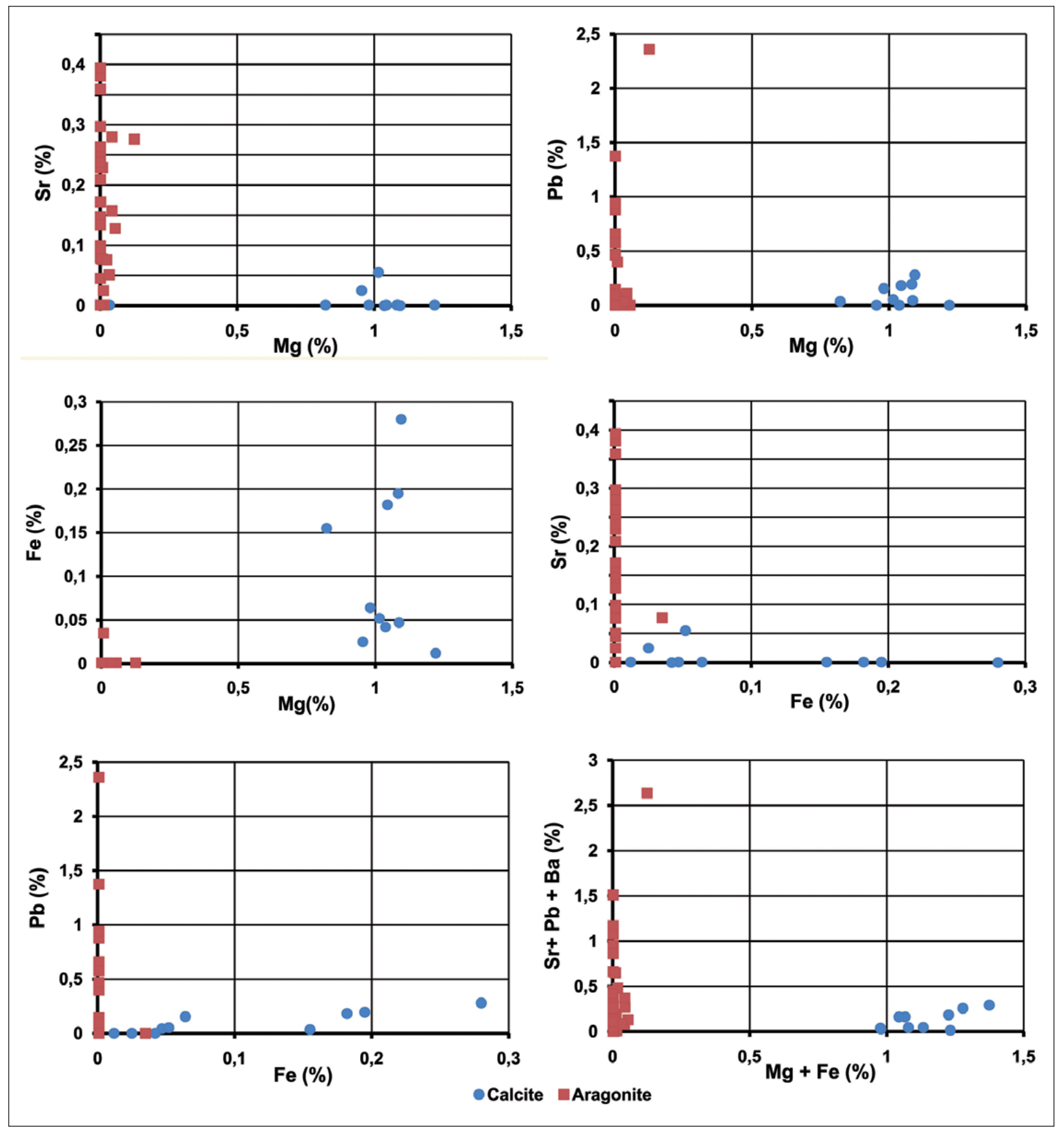

Fig. 15: Chemical compostion of aragonite and calcite in the upper half of SB5 (see Tab. 2).

1) deposition of a layer of oxides and hydro-oxides of hydrated metals, clay minerals and amorphous minerals;

2) nucleation of the aragonite crystals, initially fan disposed, which include the oxides and hydro-oxides in their crystallographic vacuums, and the ions, which promote their deposit, into the crystal network in a polymorphic substitution of $\mathrm{Ca}^{2+}$;
3) deposition of the newly formed calcite crystal, almost free of turbidity, that, when present, is concentrated in thin serrate bands which highlight the faces of the growth of crystals that grew in optical continuity.

In some cases the transition from phase 2 and 3 is neat and is represented by an extremely thin aragonite layer, where the mineral individuals are always "needleshaped" and are without impurities. When the transition 
is gradual the deposit is represented by an intermediate event between the transformation of aragonite into calcite.

In the first case it could be imagined that the contribution of inhibitor ions of calcite finished suddenly due to a net change of the hydrochemistry of the percolation water. The changing phase would be abrupt and marked by an extremely thin aragonite layer, without impurities, deposited by kinetic energy of the growth of previous aragonite individual crystals. In the second case the concentration of these ion mixtures would have gradually decreased and the changing phase would be represented by a layer of polymorphic transformation of aragonite into calcite.

The aragonite-calcite banding is often related to changes in the depositional environment, including temperature, drip rate, water chemistry (Baker et al. 2008;
Frisia et al. 2002). These, in turn, might be caused by climatic oscillations. The aragonite-calcite couplets in SBC1 may testify climate (or seasonal) changes occurred in the Iglesiente area during the Quaternary. Periods of minimum rain and a warmer climate would have promoted the deposition of aragonite, whilst intermediate periods with abundant rain and lower temperatures would have allowed the deposition of calcite. Finally we need to underline that the deposit of aragonite was promoted also by the specific environmental conditions of the cave, which have had an effect on the very low speed of deposition.

The average temperature of the cave during the deposition of the calcite layers must have been lower than the current cave temperature, which is around $16^{\circ} \mathrm{C}$ (Chiesi 2005). In fact, mainly aragonite is depositing in the cave today.

\section{CONCLUSIONS}

The SBCS has undergone at least nine speleogenetical phases that can be deduced from the geological history of the area, from detailed morphological studies and from an analysis of speleothems. The caves have formed by a combination of rising thermal waters, percolating meteoric waters and aggressive fluids derived from the oxidation of the polymetallic sulphides. The size of the present-day voids has probably been reached at the end

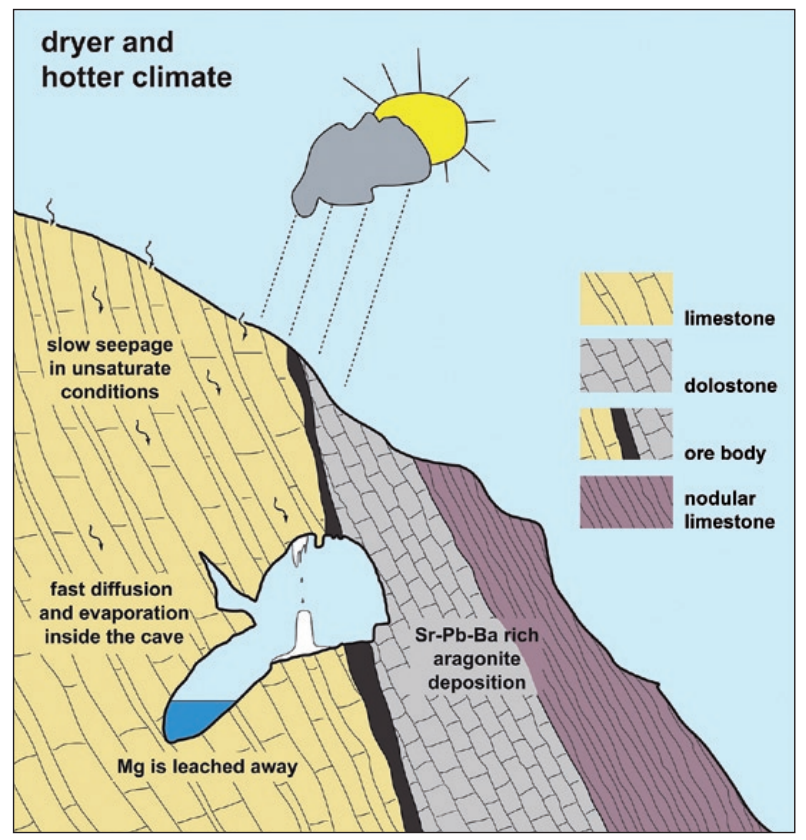

Fig. 16: Depositional processes in SBC1. See text for explanation. of the Palaeozoic. Most of the speleothems, instead, appear to be of much younger age, mostly restricted to Quaternary.

The results obtained by mineralogical, chemical and textural analysis applied on the Quaternary speleothems of SBCS allowed to obtain a general view of the present hydrochemical fluctuations in the karst system; the hydrochemistry of the rain waters of the area, which

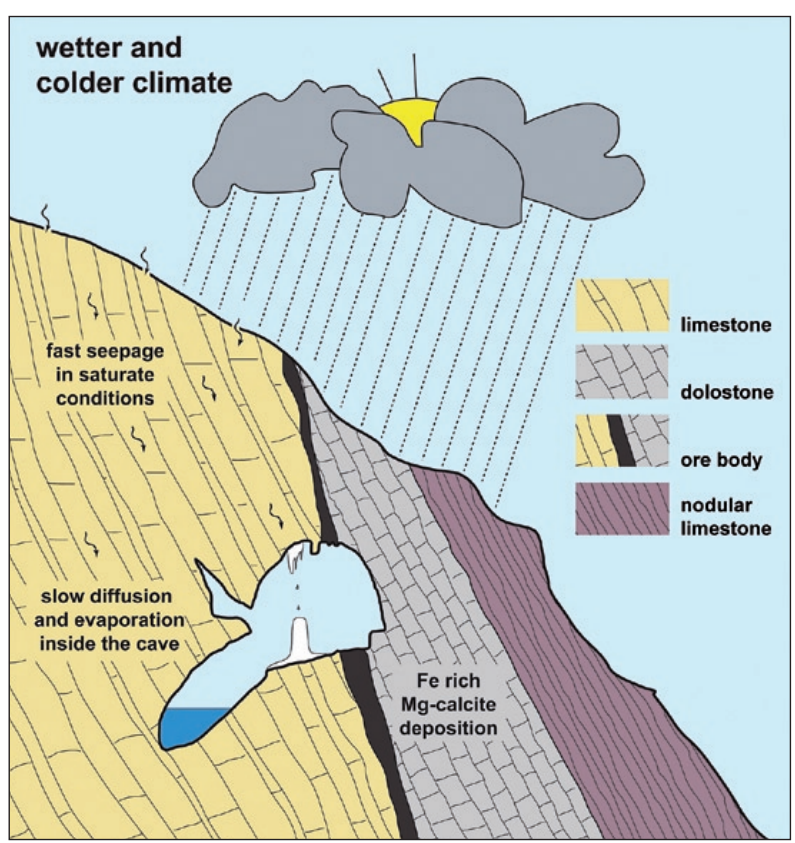


govern the modification of the carbonate depositions, probably reflect the variations of rainfall and temperature in the area above the cave during the speleothem deposition period. In particular it is possible to assume that, for the speleothems of the SBCS, the mineralogical phase aragonite was deposited during periods when the climate in the Iglesias area was warmer and less humid; on the contrary, the deposition of calcite occurred in periods that were shorter in time, cooler and with more rainfall (Fig. 16).

\section{ACKNOWLEDGEMENTS}

Access to the SBCS has been possible thanks to the collaboration of IGEA S.p.A. (Iglesias, Sardinia) and their qualified personnel. Dr. Simona Bigi has helped during the Microprobe analysis, Dr. Pierluigi Fabbri worked with the SEM, Dr. Fabio Gamberini assisted during the thin section preparation. U/Th dating was carried out by
Andrea Borsato. Silvestro Papinuto, Angelo Naseddu and Alberto Muntoni helped during the drilling campaigns. Comments by Karel Zak and an anonymous reviewer on an early version of this paper have been greatly appreciated.

\section{REFERENCES}

Arisci, A., De Waele, J., Di Gregorio, F., Ferrucci, I., Follesa, R. \& G. Piras, 2002: The Human Factor in Natural and Cultural Landscapes: the Geomining Park of Sardinia.- In: Parkes, M. (ed.) Proceedings of the International Conference on "Natural and Cultural Landscapes the Geological Foundation", 9-11 September 2002, Dublin. Royal Irish Academy, 287290, Dublin.

Badino, G. \& M. Messina, 2005: L'esplorazione della grotta di Santa Barbara 2.- Memorie dell'Istituto Italiano di Speleologia, 17, 93-98.

Baker, A., Smith, C. L., Jex, C., Fairchild, I. J., Genty, D. \& L. Fuller, 2008: Annually Laminated Speleothems: a Review.- International Journal of Speleology, 37, 193-206.

Bechstadt, T. \& M. Boni, 1996: Sedimentological, stratigraphical and ore deposits field guide of the autochtonous Cambro-Ordovician of Southwestern Sardinia.- Memorie descrittive della Carta Geologica d'Italia, 48, 1-390.

Bini, A., Cremaschi, M., Forti, P. \& G. Perna, 1988: Paleokarstic fills in Iglesiente (Sardinia, Italy); sedimentary processes and age.- Annales de la Société géologique de Belgique, 111, 149-161.

Boni, M. \& E. Crescenzi, 1988: Caratteri della mineralizzazione del Contatto Ovest, "Miniera di San Giovanni” (Iglesias, Sardegna Sud-occidentale).Rendiconti della Società Geologica Italiana, 11, 93-96.
Carmignani, L., Oggiano, G., Barca, S., Conti, P., Salvadori, I., Eltrudis, A., Funedda, A., \& S. Pasci, 2001: Geologia della Sardegna. Note illustrative della Carta Geologica della Sardegna a scala 1:200.000.- Memorie Descrittive della Carta Geologica d'Italia, Roma, Istituto Poligrafico e Zecca dello Stato, pp. 1-283, Rome.

Cheng, H., Edwards, R. L., Hoff, J., Gallup, C.D., Richards, D.A. \& Y. Asmerom, 2000: The half-lives of uranium-234 and thorium-230.- Chemical Geology, 169, 17-33.

Chiesi, M., 2005: Il pre-monitoraggio dei parametri ambientali della Grotta di Santa Barbara (Miniera di San Giovanni, Iglesias).- In: De Waele, J. \& A. Naseddu (eds.) Le Grotte di Miniera: tra economia mineraria ed economia turistica. Memorie dell'Istituto Italiano di Speleologia, 17, pp. 23-34, Bologna.

Cigna, A. A., 1978: A classification of karstic phenomena.- International Journal of Speleology, 10, 3-9.

Civita, M., Cocozza, T., Forti, P., Perna, G. \& B. Turi, 1983: Idrogeologia del bacino minerario dell'Iglesiente (Sardegna sud-occidentale).- Memorie dell'Istituto Italiano di Speleologia, 2, 1-139.

Cortecci, G., Fontes, J.C., Maiorani, A., Perna, G., Pintus, E. \& B. Turi, 1989: Oxygen, sulfur, and strontium isotope and fluid inclusion studies of barite deposits from the Iglesiente-Sulcis mining district, southwestern Sardinia, Italy.- Mineralium Deposita, 24, $34-42$. 
De Vivo, B., Maiorani, A., Perna, G. \& B. Turi, 1987: Fluid inclusion and stable isotope studies of calcite, quartz and barite from karstic caves in the Masua Mine, southwestern Sardinia, Italy.- Chemie der Erde, 46, 259-273.

De Waele, J. \& P. Forti, 2006: A new hypogean karst form: the oxidation vent.- Zeitschrift fur Geomorphologie N.F. supplementband, 147, 107-127.

De Waele, J., Forti, P. \& G. Perna, 2001: Hyperkarstic phenomena in the Iglesiente mining district (SWSardinia).- In: Cidu, A. (ed.) Water-Rock Interaction 2001. A.A. Balkema, pp. 619-622, Lisse.

Fabbri, M. \& P. Forti 1986: Recenti esplorazioni nelle miniere dell'Iglesiente (Sardegna Sud Occidentale).Sottoterra, 74, 1-9.

Fairchild, I. J., Borsato, A., Tooth, A.F., Frisia, S., Hawkesworth, C.J., Huang, Y.M., McDermott, F. \& B. Spiro, 2000: Controls on trace element (Sr-Mg) compositions of carbonate cave waters: implications for speleothem climatic records.- Chemical Geology, 166, 255-269.

Forti, P., Pagliara, A., Galli, E., Rossi, A., De Waele, J., Naseddu, A. \& S. Papinuto, 2005: Studio morfologico e mineralogico di dettaglio del concrezionamento del sistema carsico di Santa Barbara (Miniera di San Giovanni, Iglesias).- Memorie dell'Istituto Italiano di Speleologia, 17, 57-68.

Forti, P. \& G. Perna, 1982: Le cavità naturali dell'Iglesiente.- Memorie dell'Istituto Italiano di Speleologia, II (1), 229.

Frau, F., De Waele, J. \& A. M. Caredda, 2005: Geochimica delle acque nelle grotte di miniera di Monte San Giovanni, Iglesias.- Memorie dell'Istituto Italiano di Speleologia, 17, 141-148.

Frisia, S., 1996: Petrographic evidences of diagenesis in some speleothems: some examples.- Speleochronos, 7, 21-30.
Frisia, S., Borsato, A., Fairchild, I.J. \& F. McDermott, 2002: Aragonite-calcite relationships in speleothems (Grotte de Clamouse, France): environment, fabrics and carbonate geochemistry.- Journal of Sedimentary Research, 72, 687-699.

Klimchouk, A. B., 2007: Hypogene speleogenesis: hydrogeological and morphogenetic perspective.- National Cave and Karst Research Institute, pp. 106, Carlsbad, USA.

Klimchouk, A. B., 2009: Morphogenesis of hypogenic caves.- Geomorphology, 106, 100-117.

Ludwig, K. R., Vollmer, R., Turi, B., Simmons, K.R. \& G. Perna, 1989: Isotopic constraints on the genesis of base-metal ores in southern and central Sardinia.European Journal of Mineralogy, 1, 657-666.

Pagliara, A., 2009: Studio mineralogico e petrografico e ricostruzione peleoclimatica dell'area della Grotta di Santa Barbara, Sardegna.- PhD thesis, Università di Bologna, pp. 256.

Pagliara, A., Forti, P. \& Y. Y. Shopov, 2008: Studio delle fluttuazioni climatiche quaternarie dell'Iglesiente mediante l'analisi di speleotemi della Grotta di Santa Barbara IIglesias, CA).- Memorie dell'Istituto Italiano di Speleologia, 21, 167-177.

Pillola, G. L., 1989: Trilobites du Cambrien inférieur du SW de la Sardaigne, Italie.- Paleontographica Italica, 78, 1-174.

Railsback, B., 2000: An Atlas of Speleothem Microfabrics.- [Online] Available from: http://www.gly.uga. edu/speleoatlas/SAindex1.html [Accessed 28 June 2010].

Rossetti, V. \& A. Zucchini, 1956: Baritina della Grotta di Santa Barbara.- Rendiconti del Seminario della Facoltà di Scienze Università di Cagliari, 3-4, 240255. 